\title{
DEVELOPMENT OF THE ADMINISTRATIVE LAW IN THE KYRGYZ REPUBLIC
}

The article provides an overview and stages of the development of law and legislation on administrative procedures and administrative justice in the Kyrgyz Republic. The article discusses the adoption, implementation, content and the application of the new Law on Administrative Procedure and the Administrative Procedure Code of the Kyrgyz Republic. At the beginning, the socio-political background and the rationale for the ongoing judicial reforms and the efforts of the state to strengthen the rule of law in the Kyrgyz Republic are described. A significant part of article considers steps for developing a law on administrative procedures of the Kyrgyz Republic and the problems associated with its development. Then, the content and issues of implementation and the problems of the practical application of the new law on administrative procedures of the Kyrgyz Republic are disclosed. A separate part is devoted to the development, content, implementation and practice of the application of the new Administrative Procedure Code of the Kyrgyz Republic. The article also outlines the problems and shortcomings in the practice of applying legal norms on administrative procedures and administrative justice in the Kyrgyz Republic.

In general, the article summarizes that a new system of administrative law has been formed in Kyrgyzstan to replace "Soviet" administrative law, but there are still problems in understanding and applying the new administrative legislation: not all the regulatory framework and practice of administrative agencies are brought into line with the new legislation; there are facts of not understanding, ignoring and not applying the new legislation by public authorities; not all curricula of higher legal education are brought in line with a new understanding of administrative law. It is necessary to continue the implementation measures to put into practice the new administrative legislation through organizational measures to educate and train law applicators, as well as the development of judicial practice in administrative cases.

Key words: administrative law, Kyrgyz Republic, administrative activity, administrative procedure, administrative act, administrative justice, administrative claim, judicial reform, state body, administrative agency (authority), regulatory legal act, inquisition principle. 


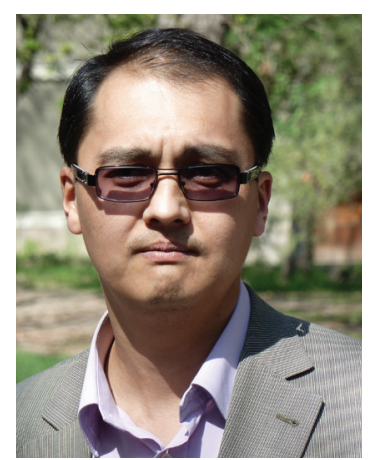

Rustam Madaliev, National Coordinator in Kyrgyzstan of the GIZ Regional Program "Promotion of the Rule of Law in Central Asia", Lecturer of the Department of Law American University of Central Asia https://orcid.org/0000-00027672-8773 rustam.madaliev@gmail.com

\section{Introduction}

Since gaining its independence, the Kyrgyz Republic has passed several stages of judicial reform. The most significant reforms began in 2010 and are still ongoing. The two revolutions (March 2005 and April 2010) and the resulting socio-political crisis required the new authorities to pay special attention not only to economic and social reforms but also to judicial reform and the rule of law strengthening. During this period, almost all codes and laws relating to the judicial and law enforcement systems have undergone major changes and innovations. The Constitution of the Kyrgyz Republic of 2011 laid down new general provisions, structure, and basics of the judicial system of the republic. To implement the norms of the Constitution, Conceptual directions were developed for further reforming the judicial system of the Kyrgyz Republic, adopted by the Decree of the President of the Kyrgyz Republic "On Measures to Improve Justice in the Kyrgyz Republic" dated August 8, 2012 (Ukaz Prezidenta Kyrgyzskoj Respubliki..., 2012). This, in fact, the Concept on judicial reform identified the main directions for reforming the judicial system and legislation in the field of the judiciary, the status of judges, administrative law and process, civil law and process, criminal law and process, criminal enforcement law, executive production, access to justice, etc. As the implementation of this Concept, a package of laws in the field of judicial reform was developed and adopted. The new Administrative Procedure Code, the Civil Procedure Code, the Criminal Code, the Criminal Procedure Code, the Criminal Enforcement Code, the Code on misdemeanors, the Code on offenses, the Law on the Basics of Administrative Activity and Administrative Procedure, the Law on Enforcement Procedure, the Law on Free Legal Aid, as well as amendments to laws on the status of judges and judicial self-government. These codes and laws are already in place and are being actively implemented in practice.

This research will focus on the reform of administrative legislation related to the adoption of the Law on the Basics of Administrative Activity and Administrative Procedure (Zakon Kyrgyzskoj Respubliki..., 2015) and the Administrative Procedure Code (Administrativnoprotsessual'nyy kodeks..., 2017). At the same time, there will be no talk about reforming the legislation on 
administrative offenses, since these legal relations in Kyrgyzstan are no longer related to the administrative law. With the adoption and implementation of the new Code on Offenses on January 1, 2019, instead of the Code of Administrative Responsibility, such concepts as "administrative offense", "administrative responsibility" lost the adjective "administrative" and the legislator now refers these relations to the scope of the criminal law. So, there will be no talk on the administrative law in the Soviet conception, as the law on administrative offenses, but the new administrative legislation in the Western conception related to the settlement of public law disputes will be described.

First of all, it is necessary to describe the new Law "On the Basics of Administrative Activity and Administrative Procedure". This Law introduces a unified procedure for state activities and establishes uniform procedures for the activities of public authorities, regulates legal relations between authorities and individuals, legal entities in resolving public law disputes. In general, the activities of state bodies should be aimed at ensuring high-quality execution of the powers vested in them in the interests and for the public good. And such activities of state bodies should be subject to uniform, comprehensive and unified rules. Such rules, for example, are provided for the legislature in the form of law-making procedures that directly establish the procedure for the adoption of laws. In the Kyrgyz Republic, such legislative procedures are established in the Constitution (Konstitutsiya Kyrgyzskoy Respubliki, 2011), the Law "On the Rules of Procedure of the Jogorku Kenesh (Parliament) of the Kyrgyz Republic" (Zakon "O Reglamente Zhogorku Kenesha..., 2011) and the Law "On Regulatory Legal Acts of the Kyrgyz Republic" (Zakon "O normativnykh pravovykh aktakh..., 2009). Judicial power is exercised through legal proceedings based on special procedural rules legally enshrined in the procedural laws (Administrative Procedure Code, Civil Procedure Code, Criminal Procedure Code, Code on Offenses).

The activities of executive authorities and their officials, state and municipal employees should be determined not only by a variety of material legal norms but also by a system of procedural administrative and legal norms. If legal procedures in the activities of the legislative and judicial branches of state power of the Kyrgyz Republic have come a long way in their development, having rich historical experience, that cannot be said about administrative procedures (Satarov, 2015).

Administrative procedures are a relatively new institution for Kyrgyzstan since administrative procedures began as a separate subject of legal regulation only in 2004 when the Law of the Kyrgyz Republic "On Administrative Procedures" (Zakon Kyrgyzskoy Respubliki "Ob administrativnykh..., 2004) was adopted. This law was aimed at regulating relations between an administrative body and a citizen by considering appeals of persons addressed to state bodies, local self-government bodies, and their officials, adopting an administrative act, appealing against the actions of administrative bodies, execution of an administrative act, administrative expenses, as well as compensation for harm, caused by an administrative procedure. 
Unfortunately, the Law has not been applied in the daily practice of administrative bodies since its adoption. Such a conclusion was made already in 2008 when studying the results of a survey of a large number of bodies, conducted by a working group, which included representatives of state organizations. No one of the surveyed 22 bodies or ministries included a new law at least in the regulatory sources, which are the basis of daily work (Pudelka and Deppe, 2014). The fact that the law was practically not applied by state bodies is explained by its too many declarative formulations, gaps, many reference norms, and its inappropriate systematics. As a result, the law was not integrated into the national legal system. Particularly, the Law was not based on a clear understanding of the very essence of the administrative procedure, the concept of an administrative act, its types, etc.

The lack of enforcement of this law was due to the following. Firstly, the law on administrative procedures is a new and poorly studied institution for Kyrgyzstan. Secondly, there is an alternative to this law in the form of the Law of the KR "On the Procedure for Considering Citizens' Appeals", which is stated in a more understandable language, in contrast to the law on administrative procedures. Thirdly, there were no implementation measures aimed at putting administrative procedures into practice. State officials were not trained to apply the law. No training was held, there was no media support for the Law, which would help clarify its nature, purpose, content and other circumstances.

As previously mentioned, for the first-time research in the field of application of the Law on Administrative Procedures was conducted in 2008. At the same time, the development of a new Law was started. A separate working group was created, which over about 5 years conducted this work with the support of the GIZ program "Promotion of the Rule of Law in Central Asia". As a result, a draft Law "On the Basics of Administrative Activity and Administrative Procedure" (hereinafter referred to as the Law or the Law on Administrative Procedure) was prepared, which was submitted to the Parliament at the end of 2012. After lengthy work in the parliament to discuss and promote the bill with varying successes and difficulties, the Law was ultimately passed by the Parliament and signed by the President of the Republic in July 2015. Since the Law provides for 9 months for transitional events, the Law entered into force in May 2016.

How is the new Law on Administrative Procedures fundamentally different from the old? The new Law has more precise regulation of previously undefined provisions and norms, introduces a uniform procedure for activity and establishes uniform procedures for the activities of public authorities. The role of the new Law is as follows: on the one hand, this Law establishes general rules of law for the uniform activity of government bodies and the enforcement of their decisions following constitutional principles; on the other hand, it serves as an evaluation criterion for judicial control over decisions of public authorities. That's why the focus of the Law is on the optimization, harmonization of management and administrative activities of state bodies, local authorities and their officials. 
The new Law details the procedure for implementing administrative procedures, as well as the specific terms and basic rules for the implementation of administrative procedures, the procedure for the adoption of administrative acts and their appeal, the execution of an administrative act, compensation for damage caused by an administrative procedure are established.

The law introduces new principles for the activity of government bodies, such as: the proportionality of the application of law, the presumption of guilt of an administrative body, the prohibition of abuse of formal requirements, the principle of efficiency, the principle of "more includes less" and others.

The law defined such concepts as an administrative activity, administrative procedures, and administrative act. Administrative activity - the activity of administrative bodies that makes an external influence and ends with the adoption of administrative acts, as well as an action or inaction that entails legal and/or actual consequences for individuals or legal entities. Administrative procedures actions of an administrative body based on an application from an interested person, an initiative of an administrative body to establish (provide, certify, confirm, register, secure), change or terminate rights and/or duties, including those ending with the issuance of an administrative act (its adoption, approval), or registration or registration of the interested person, his property, or the provision of funds, other property and/or condition at the expense of the state budget, from the property owned by the state or municipal property. An administrative act is an act of an administrative body or its official, at the same time: a) having a public law and individually defined character; b) having an external effect, i.e. not having an interdepartmental character; c) entailing legal consequences, i.e. establishing, modifying, terminating the rights and obligations for the applicant and/or interested person.

The law determines that an administrative act is usually adopted in writing. And when initiating an administrative procedure at the request of the addressee, only a written administrative act is accepted. At the same time, it should be noted such an innovation as an oral administrative act, as well as an administrative act in the form of light, sound signals and signs, images and in other forms provided by law. As a rule, an administrative act must be sufficiently clearly defined in form and content. For example, an oral administrative act is more difficult appealed. In this connection, the legislator obliged the public authority, upon the oral or written request of the person concerned, to draw up an oral administrative act in writing in accordance with all the requirements for a written administrative act (Boronbaeva, 2015).

One of the significant differences between the new law and the previous Law of the Kyrgyz Republic "On Administrative Procedures" is the introduction of the institution of a mandatory pre-trial procedure for appealing an administrative act in the administrative body itself or in a higher administrative body. Moreover, the law provides for exceptions to this rule. So, without observing the pre-trial procedure for the consideration of the dispute, the applicant has the right to appeal 
to the court - if the cancellation of the administrative act may entail the seizure of property against the will of the owner. In this case, the administrative act shall be recognized as invalid in court. This exception follows from the requirements of the Constitution of the Kyrgyz Republic, in accordance with Art. 12 of which the property is inviolable, no one can be arbitrarily deprived of his property, the seizure of property against the will of the owner is allowed only by decision of the court.

The applicant also has the right to appeal against the inaction of the administrative authority in an administrative procedure or in court - if during the time established by law for the administrative procedure instituted based on the application, the administrative act is not adopted by the authorized administrative body. In this case, the legislator provided a certain alternative to appeal against inaction for the applicant - either to the court or to a higher authority. In addition, the actions and inactions of an administrative authority are directly appealed in court in the absence of a higher administrative authority or higher official.

These are just some of the important provisions of the new Law, some of which have not previously been legislated, and the other part of the provisions has been concentrated on different line regulations.

It is important not only to draft and adopt a law but to effectively implement it in practice. That's why in order to implement the Law by order of the Head of the Government Office of the Kyrgyz Republic dated October 8, 2015 No. 140, a working group was formed to develop and submit to the Government of the Kyrgyz Republic a draft Plan for the implementation of the Law of the Kyrgyz Republic "On the basis of administrative activities and administrative procedures", and to further coordinate activities on the implementation of the above Law. The work of the working group was supported by the regional GIZ Program and its componentproject of the European Union "Promotion of the Rule of Law in Kyrgyzstan". First, a draft order of the Government of the Kyrgyz Republic on approval of the action plan of the Government of the Kyrgyz Republic on the implementation of the Law was developed, which was further approved by the Government and aimed at the execution by all executive bodies.

At the same time, quite a lot of work was done to analyze and identify by-laws and regulatory legal acts to be brought into line with the Law. According to the results of the analysis, the experts of the working group identified 125 regulatory legal acts (hereinafter RLA), which should be brought in accordance with the Law. These acts were subsequently subjected to a more thorough analysis together with interested state bodies. Based on the results of the working group's work with ministries and departments, amendments to 33 RLA were developed and adopted by the Government of the Kyrgyz Republic from the list of RLA identified by the working group.

The GIZ program and the EU project, together with the Government of the Kyrgyz Republic, initiated a large-scale training program for state and municipal employees on the implementation and application of the new Law. According 
to the results of the training, from May 2016 to the present time, together with the Academy of Public Administration under the President of the Kyrgyz Republic, more than 60 trainings were conducted for more than 1,400 state and municipal employees who familiarized themselves with the basics of administrative activities and administrative procedures.

Despite the enormous and large-scale work to implement the Law unfortunately the Law has not fully worked and not all state bodies apply it in their work.

By the decision of the Committee on Constitutional Legislation, state structure, Judicial Legal Issues and the Rules of the Jogorku Kenesh of the Kyrgyz Republic dated June 26, 2018, a working group was formed to study the practice of applying the Law of the Kyrgyz Republic "On the basics of administrative activities and administrative procedures". Based on the results of this study, an analytical report was prepared and, in December 2019, a decision was made by the relevant parliament committee with conclusions and recommendations for law applicants.

The Report notes that an analysis of the documents submitted and the study of the activities of state bodies and local self-government bodies revealed that in most cases the requirements of the Law are not respected. So, the Report contains the following conclusions:

- According to the results of the study the Ministry of Justice of the Kyrgyz Republic and its territorial divisions is the only body, which fully applies the Law on Administrative Procedures regarding formal requirements. Most administrative acts of the Ministry of Justice contain both a motivation part with justification and a reference to specific provisions of legislative acts, as well as a resolution part indicating the time for appealing the act and the authority where the act can be appealed, although there are some drawbacks.

- In some other bodies, including State agency on architecture and construction, State registration agency and Bishkek City Hall, the situation with the application of the Law on Administrative Procedures is gradually improving. But today this concerns exclusively the consideration of complaints about decisions and actions of lower bodies and structural units by the central apparatuses of these bodies. Although there are flaws here, these decisions on complaints are increasingly complying with the requirements of the Law. In the structural and territorial divisions of these bodies, the provisions of the Law are still not respected.

- The requirements of the Law on Administrative Procedures are either partially observed or not at all in other state bodies, their territorial divisions and local selfgovernment bodies. While the administrative acts for the most part contain some details stipulated by the Law (name of the administrative body, name of the official, date of adoption, etc.), the motivating and resolving part of the acts everywhere do not meet the requirements of the law.

- Regarding the motivation part, decisions with legal consequences for the citizen, including refusals to allocate a land plot, refusals to issue a building permit, etc. either do not contain any justification at all, or contain the shortest 
justification that does not meet the requirements of the law. Only in a few cases does the administrative act contain any reference to the legislative basis of the decision. Regarding the operative part, the verifiable decisions did not contain an explanation of the appeal procedure following the Law. The deadline for the decision to enter into force is either not indicated at all or it is indicated incorrectly (it is indicated that the decision takes effect from the moment of its registration, while following the Law on Administrative Procedures it takes effect from the day it is served). Some state bodies make decisions, which are essentially administrative acts, in the form of a letter, which makes it very problematic to appeal these letters.

- Courts and judicial practice more actively use the Law in their work, and the rules on mandatory pre-trial appeal have gained widespread application. In the first months after the enactment of the Law, there was a large percentage of citizens who did not follow the mandatory pre-trial appeal procedure being left without consideration and returning claims. This number has gradually decreased and today very few citizens and organizations turn to the courts, bypassing pre-trial appeal. Nevertheless, the quality of court decisions on the abolition of administrative acts according to other criteria and requirements of the Law is growing.

In terms of judicial control over the activities of public authorities, it is important to have a legally established procedural form separate from civil and criminal proceedings. The main content of judicial control in the field of public administration is that claimers can appeal administrative acts in courts.

Administrative proceedings are carried out according to the rules of the Administrative Procedure Code of the Kyrgyz Republic (hereinafter referred to as APC) adopted on January 25, 2017, which entered into force on July 1, 2017.

In terms of judicial control over the activities of public authorities, it is important to have a legally established procedural form separate from civil and criminal proceedings. The main content of judicial control in the field of public administration is that plaintiffs can challenge administrative acts in courts.

Administrative proceedings are carried out according to the rules of the Administrative Procedure Code of the Kyrgyz Republic (hereinafter referred to as APC) adopted on January 25, 2017, which entered into force on July 1, 2017.

For effective judicial control over the activities of administrative bodies, the Administrative Procedure Code of the Kyrgyz Republic provided for the following types of administrative claims:

1) a claim appealing an administrative act or action, which contains a requirement to cancel an administrative act or actions of the defendant in whole or in part;

2) a claim for the protection of the right, which contains a requirement on the defendant's obligation not to adopt an administrative act that burdens the claimant, or not to perform another action by the administrative authority;

3) a claim for the performance of an obligation, which contains a requirement for the obligation of the defendant to adopt an administrative act or perform certain actions; 
4) a claim to verify the legality of a regulatory legal act, which contains a requirement to invalidate a defendant's regulatory legal act;

5) a claim to verify the legality of an expired administrative act, which contains a requirement to declare unlawful the expired administrative act of the defendant.

Administrative cases in the first instance are resolved by inter-district courts (which also consider economic cases). In the second instance, administrative cases are considered by regional courts, (Bishkek city) as an appeal instance. The cassation instance is the Supreme Court, which reviews cases on the correct application of substantive and procedural law by lower courts, while evidence is collected in the courts of the first and second instances in the Supreme Court, evidence not investigated earlier, participants in the process cannot present.

Particular importance in modern judicial practice are cases on appeal of regulatory legal acts on the grounds of their failure to comply with the law. The novelty is characterized by the very nature of this category of cases, since the object of judicial appeal will be a legal act. Judicial protection in such cases affects the public interests of an indefinite circle of people, since the legal act itself extends its action to an unlimited circle of people. By considering such cases, the court exercises judicial control over the appealed normative acts of another normative act, which has great legal force and significance in the hierarchy of legal acts.

Today in the republic there is a clear understanding of the term "administrative justice" or "administrative process" used in the APC, i.e. this is legal proceedings on disputes arising from administrative-legal (public-law) relations between administrative bodies and (or) their officials, on the one hand, and individuals and legal entities, on the other hand.

When considering cases on appealing administrative acts, actions (inaction) of state bodies, local authorities, other bodies, officials, the court shall check (Article 173 of the APC):

- does the administrative act comply with the Constitution, laws and other regulatory normative legal acts of the Kyrgyz Republic;

- whether an administrative act was issued in compliance with administrative procedures prescribed by law;

- whether the procedure for adopting an act prescribed by law has been followed;

- the competence of state authorities, local authorities and their officials who have adopted the impugned act;

- whether the rights, freedoms and legitimate interests of the person who has applied to the court have been violated, or whether obstacles have been created to this person to exercise his rights, freedoms and legal interests.

It should be noted that the court, when considering and making a decision, the court is not bound by the arguments included in the claim, this rule follows from the "Inquisition principle", i.e. the active role of the court in a public legal dispute.

The "Inquisition principle" is the most important principle of the administrative process, which is characteristic in that it allows the court to conduct an objective 
investigation of the administrative case and essentially balances the position of the claimant in a dispute with the state, since the claimant is always a "weaker" participant in the process with the state powerful apparatus and features.

This concept is laid down in article 12 of the APC as follows:

- the court, not limited to the explanations, statements and proposals of the participants in the proceedings, the evidence and other materials available in the case, examines all the factual circumstances of the case that are relevant to the proper resolution of the dispute;

- the court, on its initiative or based on the application of the participants in the process, collects other evidence. The court may require the parties to submit additional information and evidence.

The new APC has absorbed all the advanced and modern ideas and developments in the field of resolving public law disputes, borrowed from the laws of Germany, Austria, Latvia, Ukraine, Azerbaijan and other countries that have a system of modern administrative law. The Administrative Procedure Code of the Kyrgyz Republic is the first such procedural law adopted among the countries of Central Asia.

Of course, the new APC and the practice of its application have their disadvantages. In particular, there are some gaps and contradictions in the text of the APC, the diverse and sometimes contradictory practice of applying the APC by the courts, the displacement of administrative and civil proceedings in judicial practice, not all judges still fully apply the Inquisition principle, etc. Some of these disadvantages will be removed with acceptance amendments to the APC and other laws that are currently developed and sent for adoption in the parliament of the republic. These amendments also provide for the formation of administrative courts based on inter-district courts with sole jurisdiction in administrative cases.

Conclusions. Thus, a new system of administrative law has already been introduced in Kyrgyzstan de jure, which is getting rid of the "Soviet" law on administrative offenses that is unusual for it. There are still de facto problems in understanding the new system of administrative law: not all the regulatory framework and practice of administrative bodies are brought into line with new legislation; there are facts of not understanding, ignoring and not applying the new legislation by public authorities; not all curricula of higher legal education are brought into line with the new understanding of administrative law and, accordingly, lecturers and students are not trained and do not receive the necessary knowledge.

In general, it is necessary to continue implementing measures to put into practice both the Law on Administrative Procedures and the APC through organizational measures to educate and train law applicants. Particularly hope is laid on judicial practice, because it is through judicial control that it is possible to effectively implement the provisions of laws, at least in the long term. 


\section{Bibliography:}

1. Указ Президента Кыргызской Республики «О мерах по совершенствованию правосудия в Кыргызской Республике» от 8 августа 2012 года. Централизованный банк данных правовой информации Кыргызской Республики. URL: http://cbd.minjust.gov.kg/act/ view/ru-ru/61388> (29.02.2020).

2. Закон Кыргызской Республики «Об основах административной деятельности и административных процедурах», 2015. Централизованный банк данных правовой информации Кыргызской Республики. URL: http://cbd.minjust.gov.kg/act/view/ru-ru/111254> (29.02.2020).

3. Административно-процессуальный кодекс Кыргызской Республики, 2017. Централизованный банк данных правовой информации Кыргызской Республики. URL: http://cbd.minjust.gov.kg/act/view/ru-ru/111520> (29.02.2020).

4. Конституция Кыргызской Республики, 2011. Централизованный банк данных правовой информации Кыргызской Республики. URL: http://cbd.minjust.gov.kg/act/view/ ru-ru/202913> (29.02.2020).

5. Закон «О Регламенте Жогорку Кенеша Кыргызской Республики», 2011. Централизованный банк данных правовой информации Кыргызской Республики. URL: http://cbd.minjust.gov.kg/act/view/ru-ru/203166> (29.02.2020).

6. Закон «О нормативных правовых актах Кыргызской Республики», 2009. Централизованный банк данных правовой информации Кыргызской Республики. URL: http://cbd.minjust.gov.kg/act/view/ru-ru/202591> (29.02.2020).

7. Сатаров У.М.(2015) Административныепроцедуры в Кыргызской Республике-этапы развития и основные принципы. Ежегодник публичного права 2015: Административный процесс. Москва : Инфотропик Медиа, 2015. С. 418.

8. Закон Кыргызской Республики «Об административных процедурах», 2004. Централизованный банк данных правовой информации Кыргызской Республики. URL: http://cbd.minjust.gov.kg/act/view/ru-ru/1401> (29.02.2020).

9. Й. Пуделька, Й. Деппе (2014), Общее административное право в государствах Центральной Азии - краткий обзор современного состояния. Ежегодник публичного права 2014: «Административное право: сравнительно-правовые подходы». Москва : Инфотропик Медиа, 2014. С. 20.

10. Боронбаева Д.С. (2015). Некоторые особенности административных процедур в Кыргызской Республике в соответствии с Законом Кыргызской Республики «Об основах административной деятельности и административных процедурах». Ежегодник публичного права 2016: Административный акт. Москва : Инфотропик Медиа, 2015. С. 279.

\section{References:}

1. Ukaz Prezidenta Kyrgyzskoj Respubliki "O merah po sovershenstvovaniju pravosudija v Kyrgyzskoj Respublike" ot 8 avgusta 2012 goda. [Decree of the President of the Kyrgyz Republic "On Measures to Improve Justice in the Kyrgyz Republic" dated August 8, 2012]. Tsentralizovannyy bank dannyh pravovoj informacii Kyrgyzskoj Respubliki. [Centralized data bank of the legal information of the Kyrgyz Republic]. Retrieved from http://cbd.minjust.gov.kg/ act/view/ru-ru/61388 [in Russian] (29.02.2020).

2. Zakon Kyrgyzskoj Respubliki „Ob osnovah administrativnoj dejatel'nosti i administrativnyh procedurah", 2015. [Law of the Kyrgyz Republic "On the Basics of Administrative Activity and Administrative Procedure", 2015]. Tsentralizovannyy bank dannyh pravovoj informacii Kyrgyzskoj Respubliki. [Centralized data bank of the legal information of the Kyrgyz Republic]. Retrieved from http://cbd.minjust.gov.kg/act/view/ru-ru/111254 [in Russian]. (29.02.2020). 
3. Administrativno-protsessual'nyy kodeks Kyrgyzskoy Respubliki, 2017. [The
[The Administrative Procedure Code of the Kyrgyz Republic, 2017]. Tsentralizovannyy bank dannykh pravovoy informatsii Kyrgyzskoy Respubliki. [Centralized data bank of the legal information of the Kyrgyz Republic]. Retrieved from http://cbd.minjust.gov.kg/act/view/ru-ru/111520 [in Russian]. (29.02.2020).

4. Konstitutsiya Kyrgyzskoy Respubliki, 2011. [Constitution of the Kyrgyz Republic, 2011]. Tsentralizovannyy bank dannykh pravovoy informatsii Kyrgyzskoy Respubliki. [Centralized data bank of the legal information of the Kyrgyz Republic]. Retrieved from: http://cbd.minjust.gov.kg/ act/view/ru-ru/202913 [in Russian]. (29.02.2020).

5. Zakon „O Reglamente Zhogorku Kenesha Kyrgyzskoy Respubliki”, 2011. [Law “On the Rules of Procedure of the Jogorku Kenesh of the Kyrgyz Republic", 2011]. Tsentralizovannyy bank dannykh pravovoy informatsii Kyrgyzskoy Respubliki. [Centralized data bank of the legal information of the Kyrgyz Republic]. Retrieved from: http://cbd.minjust.gov.kg/act/view/ ru-ru/203166 [in Russian]. (29.02.2020).

6. Zakon „O normativnykh pravovykh aktakh Kyrgyzskoy Respubliki”, 2009. [Law "On Regulatory Legal Acts of the Kyrgyz Republic”, 2009]. Tsentralizovannyy bank dannykh pravovoy informatsii Kyrgyzskoy Respubliki. [Centralized data bank of the legal information of the Kyrgyz Republic]. Retrieved from: http://cbd.minjust.gov.kg/act/view/ru-ru/202591 [in Russian]. (29.02.2020).

7. Satarov U.M. (2015). Administrative procedures in the Kyrgyz Republic - stages of development and basic principles [Administrativnye procedury v Kyrgyzskoj Respublike - jetapy razvitija i osnovnye principy]. Ezhegodnik publichnogo prava 2015: Administrativnyj process. [Public Law Yearbook - 2015: Administrative justice]. Moscow : Infotropic Media, 2015. P. 418. [in Russian].

8. Zakon Kyrgyzskoy Respubliki "Ob administrativnykh protsedurakh", 2004. [Law of the Kyrgyz Republic "On Administrative Procedures", 2004]. Tsentralizovannyy bank dannykh pravovoy informatsii Kyrgyzskoy Respubliki. [Centralized data bank of the legal information of the Kyrgyz Republic]. Retrieved from: http://cbd.minjust.gov.kg/act/view/ru-ru/1401 [in Russian]. (29.02.2020).

9. Pudelka J., Deppe J. (2014). Obshcheye administrativnoye pravo v gosudarstvah Tsentral'noy Azii - kratkiy obzor sovremennogo sostoyaniya [General Administrative Law in Central Asian States - A Brief Overview of the Current Situation]. Yezhegodnik publichnogo prava - 2014: "Administrativnoye pravo: sravnitel'no-pravovyye podkhody" [Public Law Yearbook - 2014: “Administrative Law: Comparative Legal Approaches"]. Moscow : Infotropic Media, 2014. P. 20. [in Russian].

10. Boronbaeva D.S. (2015). Nekotorye osobennosti administrativnyh procedur v Kyrgyzskoj Respublike v sootvetstvii s Zakonom Kyrgyzskoj Respubliki "Ob osnovah administrativnoj dejatel'nosti i administrativnyh procedurah" [Some features of administrative procedures in the Kyrgyz Republic in accordance with the Law of the Kyrgyz Republic "On the basics of administrative activities and administrative procedures"]. Ezhegodnik publichnogo prava 2016: Administrativnyj akt. [Public Law Yearbook 2016: Administrative Act]. Moscow : Infotropic Media, 2015. P. 279. [in Russian]. 


\title{
РОЗВИТОК АДМІНІСТРАТИВНОГО ПРАВА В КИРГИЗЬКІЙ РЕСПУБЛІЦІ
}

\author{
Рустам Мадалієв, \\ національний координатор в Киргизстані Регіональної програми GIZ \\ "Сприяння правової державності в країнах Центральної Азії», \\ викладач Департаменту права \\ Американського університету в Центральній Азії \\ https://orcid.org/0000-0002-7672-8773 \\ rustam.madaliev@gmail.com
}

У статті представлено огляд та етапи розвитку права $i$ законодавства про адміністративні процедури й адміністративного судочинства в Киргизькій Республічі. У статті розглядаються питання прийняття, реалізації, змісту $i$ застосування нового Закону про адміністративне судочинство і Адміністративно-прочесуального кодексу Киргизької Республіки.

На початку описуються сочіально-політичний фон і обтрунтування проведених судових реформ, атакож зусилля держави по зміцненню верховенства законув Киргизькій Республічі. Значна частина статті розглядає кроки по розробці закону про адміністративні процедури Киргизької Республіки і проблеми, пов'язані з його розробкою. Потім розкриваються зміст і питання реалізацї та проблеми практичного застосування нового Закону про адміністративні процедури Киргизької Республіки. Окрема частина присвячена розробиі, змісту, впровадження і практику застосування нового Адміністративно-процесуального кодексу Киргизької Республіки. У статті також викладені проблеми і недоліки в практиці застосування правових норм про адміністративні процедури $i$ адміністративному судочинстві в Киргизькій Республіиі.

Загалом у статті констатується, щз в Киргизстані сформувалася нова система адміністративного права замість «радянського» адміністративного права, однак ще $\epsilon$ проблеми в розумінні та застосуванні нового адміністративного законодавства: не вся нормативна база і практика адміністративних органів приведена у відповідність до нового законодавства; є факти нерозуміння, ігнорування і незастосування нового законодавства з боку органів державної влади; не всі навчальні програми вищої юридичної освіти приведені у відповідність до нового розуміння адміністративного права. Необхідно продовжувати імплементаційні заходи щзодо впровадження на практиці нового адміністративного законодавства через організаційні заходи по освіті і навчанню правозастосувача, а також розвитку судової практики в адміністративних справах.

Ключові слова: адміністративне право, Киргизька Республіка, адміністративна діяльність, адміністративні процедури, адміністративний акт, адміністративне правосуддя (судочинство), адміністративний позов, судова реформа, державний орган, адміністративний орган (орган), нормативно-правовий акт, принцип інквізиції. 